\title{
Cutaneous mast cell tumor in a captive Bush dog (Speothos venaticus): pathological and immunophenotypical aspects - case report
}

\author{
[Mastocitoma cutâneo em um cachorro-do-mato vinagre (Speothos venaticus) de cativeiro: aspectos
} patológicos e imunofenotípicos - relato de caso]

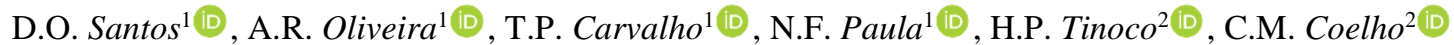

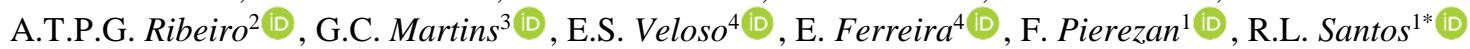 \\ ${ }^{1}$ Universidade Federal de Minas Gerais, Escola de Veterinária, Belo Horizonte, MG, Brasil \\ ${ }^{2}$ Fundação de Parques Municipais e Zoobotânica, Jardim Zoológico, Belo Horizonte, MG, Brasil \\ ${ }^{3}$ Centrovet, Belo Horizonte, MG, Brasil \\ ${ }^{4}$ Universidade Federal de Minas Gerais, Instituto de Ciências Biológicas, Belo Horizonte, MG, Brasil
}

\begin{abstract}
A senile male captive bush dog (Speothos venaticus) presented a small perianal cutaneous nodule. Histologically, there was an ulcerated round cell tumor composed of well differentiated mast cells with abundant intracytoplasmic purple Giemsa-positive granules, with a diffuse eosinophilic infiltrate. Immunohistochemistry revealed that $30 \%$ of the neoplastic cells were positive for Kit in the cytoplasm and cell membrane, and all neoplastic cells were negative for MAC and CD3. Less than $10 \%$ of the neoplastic cells were positive for Ki67. At necropsy other primary tumors were identified in this animal, including an intestinal adenoma, an adrenal cortex adenoma and a testicular interstitial cell tumor.
\end{abstract}

Keywords: wild canids, immunohistochemistry, multiple tumors

\section{RESUMO}

Um cachorro-vinagre (Speothos venaticus) apresentou um nódulo cutâneo pequeno na região perianal. Histologicamente havia neoplasia cutânea de células redondas e ulcerada, constituída por mastócitos bem diferenciados, com abundantes grânulos citoplasmáticos metacromáticos na coloração de Giemsa e infiltrado eosinofílico difuso. A imuno-histoquímica demonstrou que $30 \%$ das células neoplásicas eram positivas para a proteína Kit no citoplasma e na membrana celular. As células foram negativas para MAC e CD3. Menos de 10\% das células neoplásicas foram positivas para Ki67. Durante a necropsia, foram identificados outros tumores primários, como adenoma intestinal, adenoma cortical da adrenal e tumor de células intersticiais do testículo.

Palavras-chave: canídeos selvagens, imuno-histoquímica, tumores múltiplos

\section{INTRODUCTION}

Mast cell tumors are among the most common cutaneous tumors in domestic dogs. It is uncommon in cats and rare in other domestic animal species (Kiupel, 2017). Prognostic parameters have been studied in domestic dogs, including clinical features, histological grading, immunohistochemical evaluation, and molecular features (Horta et al., 2018). Two grading systems have been used to classify mast cell tumors in dogs based mainly on mitotic index and mast cell differentiation (Patnaik et al., 1984; Kiupel et al., 2011). Mutations in the $c$-kit gene is an important prognostic factor in

*Corresponding author: rsantos@ vet.ufmg.br

Submitted: November 27, 2020. Accepted: May 13, 2021. domestic dogs, and the aberrant subcellular localization of the KIT protein, as demonstrated by immunohistochemistry, is usually correlated with mutations in the gene, being an indicative of a high-grade tumor (Thamm et al., 2019).

Mast cell tumors are usually cutaneous or subcutaneous, although extracutaneous manifestations may occur, such as the rare intestinal presentation (Kiupel, 2017). There are no previous reports of mast cell tumors in wild canids. However, there are reported cases affecting other carnivores, particularly wild felids with cutaneous or extracutaneous forms of this tumor (Stolte and Welle, 1995; Castro et al., 2003; Graille et al., 2013). The bush dog 
(Speothos venaticus) is a small canid that occurs on parts of the Central and South America, and it is considered near threatened by the IUCN Red List (DeMatteo et al., 2011). This report aims to characterize by histopathology and immunohistochemistry a cutaneous mast cell tumor in a captive bush dog.

\section{CASE REPORT}

A senile male captive bush dog, housed at the Belo Horizonte zoological garden, presented recurrent dermatitis that was presumptively diagnosed as atopic dermatitis. The animal was anesthetized for physical evaluation, in which a small and ulcerated perianal nodule was found. The nodule was subjected to excisional biopsy and submitted for histopathological evaluation. Grossly, the nodule was small, with approximately $1 \mathrm{~cm}$ of diameter, elevated, soft and whitish on its cutting surface. Fragments from the nodule were fixed in $10 \%$ formalin buffered solution, dehydrated in decreasing dilutions of ethanol, diaphanized in xylene and embedded in paraffin, then sections of 3 to $4 \mu \mathrm{m}$ were stained with hematoxylin and eosin (HE) and Giemsa.

Histology revealed an ulcerated round cell tumor that was infiltrative, poorly demarcated, and not encapsulated (Fig. 1a). Neoplastic cells were well differentiated mast cells organized in sheets and confined to the superficial dermis (Fig. 1a,b). Cytoplasm was slightly eosinophilic with moderate amount of purple metachromatic granules as evidenced by Giemsa staining (Fig. 1c). Nuclei were round to oval, central, with loose chromatin and up to 3 nucleoli. Three mitoses were observed in 10 high magnification fields (400x). Although neoplastic cells did not reach the edges of the tissue sample, there was evidence of blood vessels infiltration. There was an extensive area of ulceration of the adjacent epidermis with moderate lymphohistiocytic and neutrophilic inflammatory infiltrate. A diffuse moderate eosinophilic infiltrate was evident among neoplastic cells. Based on histologic and histochemistry morphology the neoplasm was diagnosed as a cutaneous low grade (Kiupel et al., 2011) and grade I (Patnaik et al., 1984) mast cell tumor.

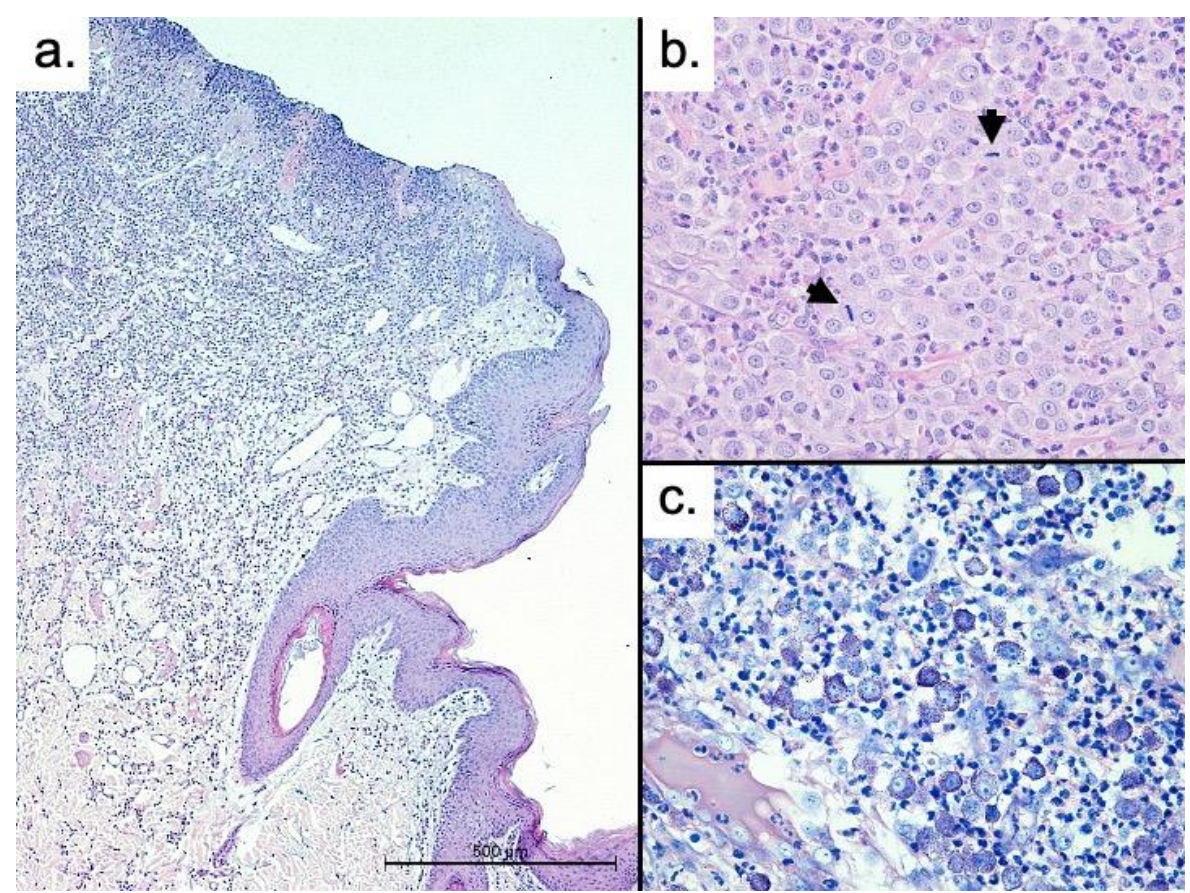

Figure 1. Cutaneous mast cell tumor in a bush dog (Speothos venaticus). a. Ulcerated, infiltrative, poorly demarcated, and non-encapsulated round cell neoplasm confined to superficial dermis, HE, 50x. b. Well differentiated neoplastic mast cells with mild nuclear and cellular pleomorphism and mitotic figures (arrows). Marked infiltration of eosinophils. HE, 400x. c. Moderate number of purple granules at the cytoplasm of the neoplastic cell, characterizing the mast cell origin, Giemsa, 400x. 
Additionally, immunohistochemistry was performed to further characterize the tumor. For antigen retrieval, sections were incubated for 2 minutes in Target Retrieval Solution Citrate $\mathrm{pH}$ 6.0 (Dako Cytomation, Glostrup, Denmark) in pressurized humid heat at $125^{\circ} \mathrm{C}$ (Pascal Pressure Cooker; Dako Cytomation, Glostrup, Denmark), and cooled at room temperature. The sections were then incubated with primary antibodies for
16 hours, at $4^{\circ} \mathrm{C}$, using specific dilutions for each primary antibody (see Table 1), followed by amplification by HRP Polymer (Novolink Polymer Detection System; Leica Biosystems, Newcastle upon Tyne, UK) and 1 minute incubation with chromogen 3'3diaminobenzidine (Liquid DAB + Substrate Chromogen System; Dako North America, Via Real Carpinteria, CA, USA).

Table 1. Immunohistochemistry protocol for detection of MAC, CD3, c-KIT, and Ki67*

\begin{tabular}{ccccccc}
\hline Antibody & Manufacturer & Clone & Dilution & $\begin{array}{c}\text { Incubation } \\
\text { time (h) }\end{array}$ & Antigen retrieval** & Amplification \\
\hline MAC387 & AbdSerotec & MCA874G & $1: 400$ & 16 & Citratebuffer+Pascal & Novolink \\
CD3 & Dako & Polyclonal & $1: 300$ & 16 & Citratebuffer+Pascal & Novolink \\
c-KIT & Dako & Polyclonal & $1: 800$ & 16 & Citratebuffer+Pascal & Novolink \\
Ki-67 & Dako & MIB-1 & $1: 50$ & 16 & Citratebuffer+Pascal & Novolink \\
\hline
\end{tabular}

*MAC: anti-macrophage; CD3: anti-T lymphocyte; c-KIT: anti-KIT; Ki-67: proliferation cell marker.

** Pascal - Pressurized humid heat $\left(125^{\circ} \mathrm{C}\right)$.

Immunohistochemistry details are described in Table 2. Neoplastic cells were negative for MAC and CD3, while immunolabeling was present in inflammatory cells within the tumor that served as internal controls demonstrating that these primary antibodies do cross react with this specific species. Anti-KIT protein was weakly positive on the membrane and cytoplasm in more than $30 \%$ of neoplastic cells (Fig. 2a and c). Nuclei were positive for Ki67 in less than $10 \%$ of the neoplastic cells (Fig. 2b and d).

Due to the well-differentiated and superficial dermal localization of this neoplasm, no additional treatment was performed. Besides the mast cell tumor, the animal presented a nonresponsive to treatment diffuse dermatitis with progressive weight loss and a nodule on the colon mucosa found by endoscopic evaluation. Based on the advanced age and poor prognosis of co-morbidities, the animal was euthanized approximately three months after the diagnosis of cutaneous mast cell tumor. Necropsy was performed immediately after death. Briefly, necropsy and histopathology revealed an intestinal adenoma (Fig. 3a,b), an adrenal cortex adenoma (Fig. 3c,d) and a testicular interstitial cell tumor (Fig. 3e). No gross or microscopic mast cell tumor metastasis were observed at the time of necropsy.

\section{DISCUSSION}

To the best of our knowledge, this is the first report of a cutaneous mast cell tumor in a bush $\operatorname{dog}$ (Speothos venaticus). The literature on diseases that affect bush dogs is extremely scarce, with rare reports of infectious diseases and only one report of neoplastic disease, namely an extranodal lymphoma affecting an animal from the same institution of the present case (Carvalho et al., 2020). Importantly, this species has a high risk of extinction in the wild and there are only a few individuals in captivity (DeMatteo et al., 2011), which makes the study of diseases in this species particularly important under a perspective of conservation medicine.

Table 2. Immunohistochemistry (IHC) results for MAC, CD3, KIT protein and Ki67 expression in the cutaneous mast cell tumor neoplastic cells in a bush dog (Speothos venaticus)

\begin{tabular}{lll}
\hline IHC antibody & Results & Localization \\
\hline MAC & Negative & - \\
CD3 & Negative & - \\
KIT protein & $>30 \%$ & Membrane and cytoplasm \\
Ki67 & $<10 \%$ & Nuclei \\
\hline
\end{tabular}




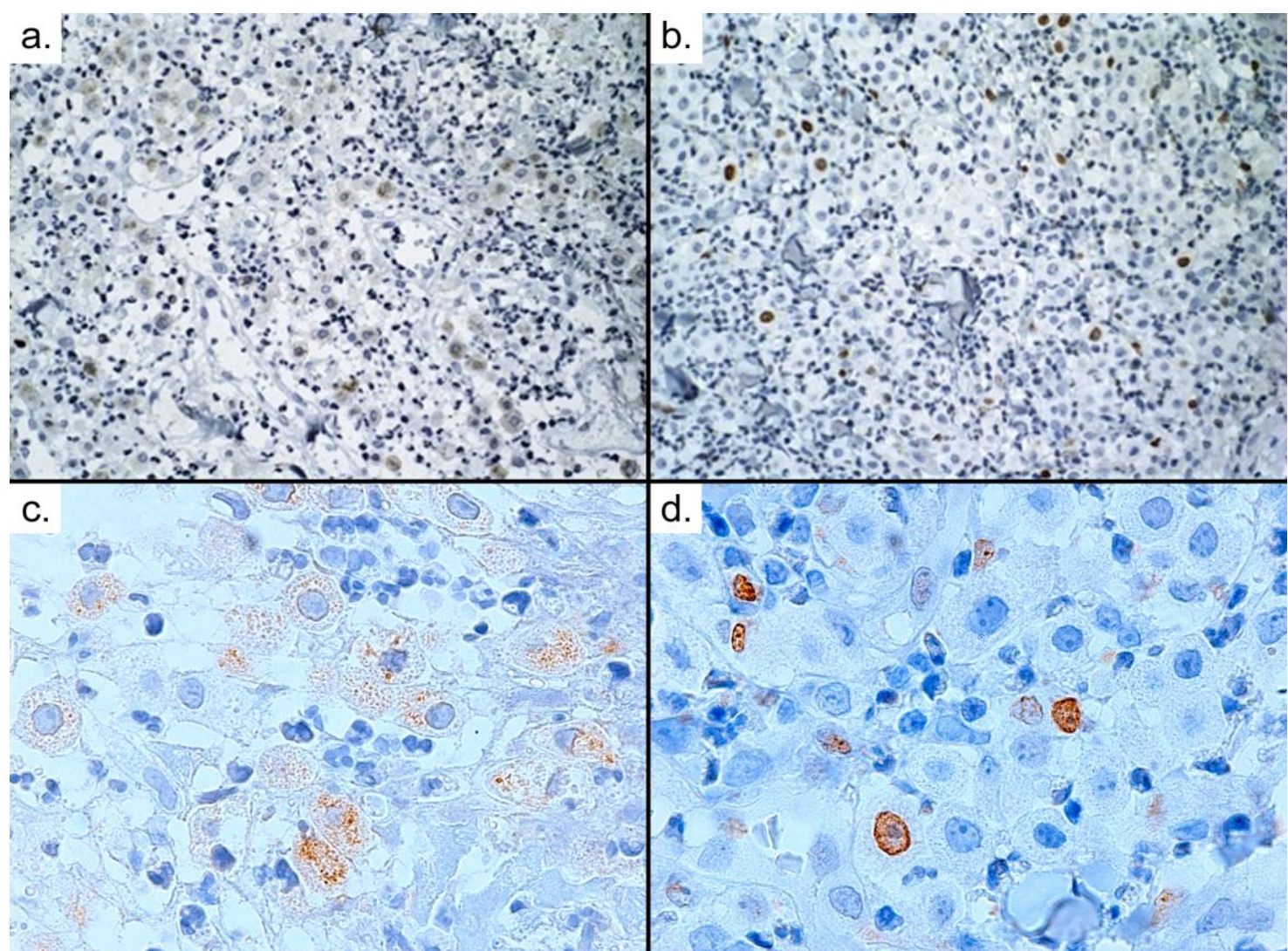

Figure 2. Immunohistochemistry of a cutaneous mast cell tumor in a bush dog (Speothos venaticus). a. Mild immunolabeling of KIT protein, observed both at cell membrane and cytoplasm, from > 30\% neoplastic cells, DAB, 200x. b. Proliferation index using Ki67 with nuclear immunolabeling in $<10 \%$ of neoplastic cells, DAB, 200x. c. Higher magnification of a, DAB, 1000x. d. Higher magnification of b, DAB, 1000x.

Although mast cell tumors are very common in domestic dogs, no reports of this neoplasm affecting wild canids is available. However, few cases of this tumor in other wild mammals have been reported, including a cutaneous mast cell tumor in an Indian lioness (Panthera leo) (Stolte \& Welle, 1995), a visceral mast cell tumor in a black jaguar (Panthera onca) (Castro et al., 2003), a visceral mast cell tumor with mastocytemia in a Sumerian tiger (Panthera tigris) (Graille et al., 2013) and a pulmonary mast cell tumor in a Pacific walrus (Odobenus rosmarus divergens) (Seguel et al., 2016).

The bush dog in this case developed a low-grade cutaneous mast cell tumor with low mitotic and proliferation index (ki67 immunolabeling < $10 \%$ ) and was treated exclusively with surgical excision. Importantly, no macro or micro metastases were observed, even three months after surgical procedure. In domestic dogs, proliferation index is directly correlated with survival and compatible with two-tie system graduation (Vascellari et al., 2013). Dogs with ki67 immunolabeling $<10.6 \%$ rarely dies due to mast cell tumor complications (Vascellari et al., 2013). In our case the proliferation index was compatible with histopathological graduation and was interpreted as predictive of the neoplasm behavior.

Another prognostic factor frequently used for mast cell tumors in domestic dogs is the mutation of the $c$-kit gene. In immunohistochemistry, the KIT protein is normally visualized on the cell membrane, and in cases of atypical localization, such as cytoplasmic, it may indicate a mutation in the gene and a more unfavorable prognosis (Thamm et al., 2019). Cytoplasmatic immunolabeling of KIT protein is also associated with local recurrence and metastasis (Thompson et al., 2011). However, in this case, no local 
recurrence was observed during the three months of evaluation and as mentioned before, there were no evidences of macro and micro metastasis. Therefore, it was not possible to establish a correlation between KIT protein immunolabeling and the behavior of this neoplasm in this specific case. In addition, the sample available for immunohistochemistry in this case had no margins so it was not possible to precisely determine whether non neoplastic mast cells had membrane KIT immunolabeling. Further studies are needed to demonstrate the relevance of the $c$-kit gene mutation for the prognosis of mast cell tumors in wild canids.
Importantly, this bush dog also had other tumors, observed at necropsy and identified as adrenal cortex adenoma, intestinal adenoma and a testicular interstitial cell tumor. Multiple neoplasms are commonly observed in domestic dogs, especially with advanced age (Komsta \& Łopuszyński, 2008; Priester, 1977). In captive wild animals, neoplasms are frequently reported and are believed to be related to senility (Oliveira et al., 2018; Carvalho et al., 2018; Eckstein et al., 2020).

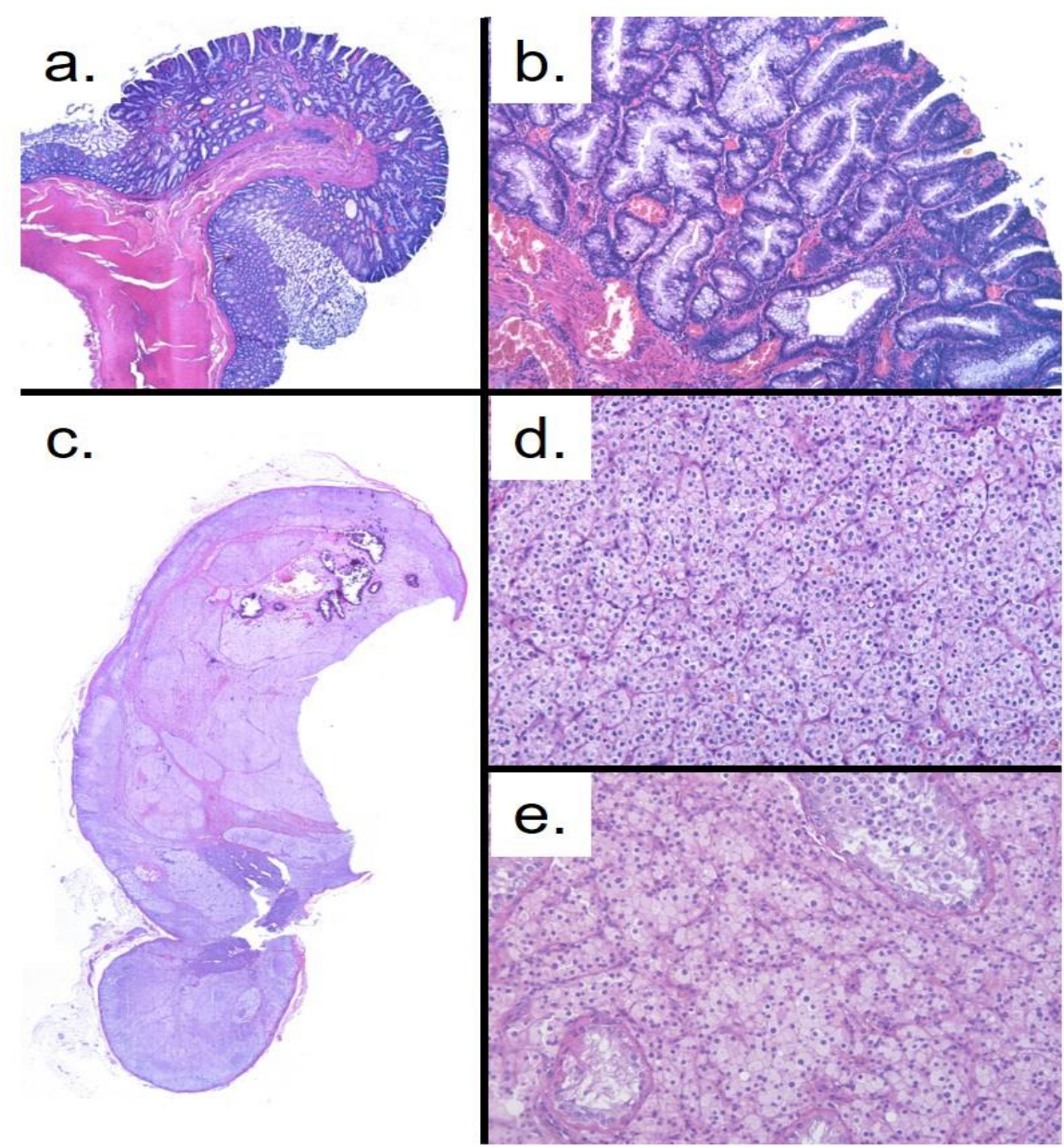

Figure 3. Intestinal adenoma, adrenal cortex adenoma and testicular interstitial cell tumor in a bush dog (Speothos venaticus). a,b. Intestinal adenoma. a. Intestinal mucosa with a polypoid proliferation projecting into the lumen. HE, 50x. b. Well differentiated epithelial cells organized in tubules with abundant goblet cells. HE, 100x. c,d. Adrenal cortex adenoma. c. Cortical expansive neoplasm organized in nests separated by connective tissue and with multifocal areas of mineralization. HE, 50x. d. Well differentiated neoplastic cells with minimal cellular and nuclear pleomorphism and vacuolated cytoplasm. HE, 200x. e. Testicular interstitial cell tumor. Well differentiated interstitial neoplastic cells with vacuolated cytoplasm between seminiferous tubules. HE, 200x. 


\section{CONCLUSION}

This is the first report of cutaneous mast cell tumor in a bush dog (Speothos venaticus), an endangered species with few reports of tumor. Here, the mast cell tumor was characterized by pathological, histochemical and immunohistochemical analysis. Beside the cutaneous tumor, the same individual presented multiple primary different neoplasms, such as an intestinal adenoma, an adrenal cortex adenoma and a testicular interstitial cell tumor.

\section{ACKNOWLEDGEMENTS}

Work in RLS lab is supported by $\mathrm{CNPq}$ (Conselho Nacional de Desenvolvimento Científico e Tecnológico, Brazil), FAPEMIG (Fundação de Amparo a Pesquisa do Estado de Minas Gerais, Brazil), and CAPES (Coordenação de Aperfeiçoamento de Pessoal de Nível Superior, Brazil). RLS has a fellowship from CNPq (Brazil).

\section{REFERENCES}

CARVALHO, T.F.; FROIS, D.N.; TINOCO, H.P. et al. Malignant pancreatic gastrinoma in a maned wolf (Chrysocyon brachyurus): case report. Arq. Bras. Med. Vet. Zootec., v.70, p.475-478, 2018.

CARVALHO, T.F.; PESSANHA, A.T.; PIEREZAN, F. et al. Extranodal lymphoma in a bush dog (Speothos venaticus) - case report. Arq. Bras. Med. Vet. Zootec., v.72, p.754-760, 2020.

CASTRO, M.B.; WERTHER, K.; GODOY, G.S. et al. Visceral mast cell tumor in a captive black jaguar (Panthera onca). J. Zoo Wildl. Med., v.34, p.100-102, 2003.

DEMATTEO, K.; MICHALSKI, F.; LEITEPITMAN, M.R.P. Speothos venaticus. The IUCNRed List of Threatened Species, 2011. Available in: http://dx.doi.org/10.2305/IUCN.UK.2011-

2.RLTS.T20468A9203243.en. Accessed in: 7 Oct. 2020 .

ECKSTEIN, C.; TINOCO, H.P.; COELHO, C.M. et al. Cutaneous metastatic melanoma in a Siberian tiger (Panthera tigris altaica) - case report. Arq. Bras. Med. Vet. Zootec., v.72, p.921-925, 2020.

GRAILlE, M.; HUYGHE, F.P.; NICOLIER, A. Mastocytemia associated with a visceral mast cell tumor in a Sumatran tiger (Panthera tigris). J. Zoo Wildl. Med., v.44, p.189-192, 2013.
HORTA, R.S.; LAVALLE, G.E.; MONTEIRO, L.N. et al. Assessment of canine mast cell tumor mortality risk based on clinical, histologic, immunohistochemical, and molecular features. Vet. Pathol., v.55, p.212-223, 2018.

KIUPEL, M. Mast cell tumors. In: MEUTEN, D.J. (Ed.). Tumors in domestic animals. Iowa: John Wiley \& Sons Inc., 2017. p.176-202.

KIUPEL, M.; WEBSTER, J.D.; BAILEY, K.L. et al. Proposal of a 2-tier histologic grading system for canine cutaneous mast cell tumors to more accurately predict biological behavior. Vet. Pathol., v.48, p.147155,2011

KOMSTA, R.; ŁOPUSZYŃSKI, W. Multiple primary tumours a in dog. A case report. Bull. Vet. Inst. Pulawy, v.52, p.481-484, 2008.

OLIVEIRA, A.R.; CARVALHO, T.F.; ARENALES, A. et al. Metastatic oral squamous cell carcinoma in a captive common hippopotamus (Hippopotamus amphibius). Braz. J. Vet. Pathol., v.11, p.64-67, 2018.

PATNAIK, A.K.; EHLER, W.J.; MACEWEN, E.G. Canine cutaneous mast cell tumor: morphologic grading and survival time in 83 dogs. Vet. Pathol., v.21, p.469-474, 1984.

PRIESTER, W.A. Multiple primary tumors in domestic animals. A preliminary view with particular emphasis on tumors in dogs. Cancer, v.40, p.18451848, 1977.

SEGUEL, M.; STIMMELMAYR, R.; HOWERTH, E. et al. Pulmonary mast cell tumor and possible paraganglioma in a free-ranging Pacific walrus (Odobenus rosmarus divergens), Barrow, Alaska, USA. J. Wildl. Dis., v.52, p.407-410, 2016.

STOLTE, M.; WELLE, M. Cutaneous mast cell tumours in a lion (Panthera leo): a light and transmission electron microscopical study. J. Comp. Pathol., v.113, p.291-294, 1995.

THAMM, D.H.; AVERY, A.C.; BERLATO, D. et al. Prognostic and predictive significance of KIT protein expression and c- kit gene mutation in canine cutaneous mast cell tumours: a consensus of the Oncology- Pathology Working Group. Vet. Comp. Oncol., v.17, p.451-455, 2019.

THOMPSON, J.J.; YAGER, J.A.; BEST, S.J. et al. Canine subcutaneous mast cell tumors: cellular proliferation and KIT expression as prognostic indices. Vet. Pathol., v.48, p.169-181, 2011.

VASCELLARI, M.; GIANTIN, M.; CAPELLO, K. et al. Expression of Ki- 67, BCL- 2, and COX- 2 in canine cutaneous mast cell tumors: association with grading and prognosis. Vet. Pathol., v.50, p.110-121, 2013. 